\title{
A dialogue with Sen's Theory of capabilities and its implications for our National Democratic Revolution
}

\begin{tabular}{|c|c|}
\hline $\begin{array}{l}\text { Author: } \\
\text { Vuyani Vellem }\end{array}$ & \\
\hline $\begin{array}{l}\text { Affiliation: } \\
{ }^{1} \text { Department } \\
\text { and Christian } \\
\text { University of } \\
\text { South Africa }\end{array}$ & $\begin{array}{l}\text { fogmatics } \\
\text { Ethics, } \\
\text { retoria, }\end{array}$ \\
\hline $\begin{array}{l}\text { Project leader } \\
\text { Project numb }\end{array}$ & $\begin{array}{l}\text { V.S. Vellem } \\
\text { er: } 04425030\end{array}$ \\
\hline $\begin{array}{l}\text { Description: } \\
\text { This research i } \\
\text { research proje } \\
\text { Cohesion', dire } \\
\text { Dr. Vuyani Vell } \\
\text { Department o } \\
\text { and Christian } \\
\text { of Theology, U } \\
\text { Pretoria. }\end{array}$ & $\begin{array}{l}\text { s part of the } \\
\text { ct, 'Social } \\
\text { ected by Prof } \\
\text { em of the } \\
\text { f Dogmatics } \\
\text { Ethics, Faculty } \\
\text { niversity of }\end{array}$ \\
\hline $\begin{array}{l}\text { Correspondin } \\
\text { Vuyani Vellem } \\
\text { vuyani.vellem }\end{array}$ & $\begin{array}{l}\text { g author: } \\
\text { @up.ac.za }\end{array}$ \\
\hline $\begin{array}{l}\text { Dates: } \\
\text { Received: } 28 \mathrm{~J} \\
\text { Accepted: } 10 \\
\text { Published: } 02\end{array}$ & $\begin{array}{l}\text { uly } 2016 \\
\text { Dept. } 2016 \\
\text { Dec. } 2016\end{array}$ \\
\hline $\begin{array}{l}\text { How to cite th } \\
\text { Vellem, V., } 201 \\
\text { with Sen's The } \\
\text { capabilities an } \\
\text { implications fo } \\
\text { Democratic Re } \\
\text { HTS Teologiese } \\
\text { Theological St } \\
\text { a3581. http:// } \\
\text { org/10.4102/ }\end{array}$ & $\begin{array}{l}\text { is article: } \\
\text { 16, 'A dialogue } \\
\text { ory of } \\
\text { d its } \\
\text { r our National } \\
\text { volution', } \\
\text { Studies/ } \\
\text { udies 72(4), } \\
\text { dx.doi. } \\
\text { ts.v72i4.3581 }\end{array}$ \\
\hline $\begin{array}{l}\text { Copyright: } \\
\text { (C) 2016. The A } \\
\text { Licensee: AOS } \\
\text { is licensed und } \\
\text { Creative Comn } \\
\text { Attribution Lic }\end{array}$ & $\begin{array}{l}\text { uthors. } \\
\text { IS. This work } \\
\text { ler the } \\
\text { nons } \\
\text { ense. }\end{array}$ \\
\hline Read online: & \\
\hline 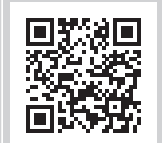 & $\begin{array}{l}\text { Scan this QR } \\
\text { code with your } \\
\text { smart phone or } \\
\text { mobile device } \\
\text { to read online. }\end{array}$ \\
\hline
\end{tabular}

In 'traditional' liberation theological discourse, especially the Latin American strand, the concept of development, desarrollismo, that is developmentalism, has been severely critiqued. In recent times, the interpretation of development shifted to a number of models, one of which has been the view of development as freedom, associated with Amartya Sen's 'capabilities theory'. While the capabilities theory ostensibly comes closer to the goals of the liberation paradigm in general, this article seeks to critically explore in dialogue with this theory of capabilities assumptions and implications of the concept of development for our national democratic revolution. A number of service delivery strikes in our land, with many poor people expecting government to 'deliver' for them, might suggest among other things that the state does 'development' for people, hence the designation of the post-1994 South African state as a 'developmental state'. This article argues that, at foundational level, development understood as liberation could help alter the assumptions that held the national democratic revolution back.

\section{Introduction}

This article basically examines the relationship between the Dependency Theory and the liberation paradigm, especially the Latin American discourse of liberation and development. By critiquing development as part of modernity, this article shows how the fallacy of the universalisation of values and systems from within Europe continues to underestimate the coloniality of power or blackness as a condition that continues to exist long after the demise of colonialism and apartheid. This article briefly engages Sen's Theory of capabilities to establish a convergence between freedom as development and the quest for breaking with dependencies, a vision of liberation. In light of this discussion, the article broadly asks: Is there a relationship between the Constitution of South African and the concept of development? What constitutional obligation does the state have in the development of the country? What model of development would be appropriate for such a task? The article concludes by arguing that a constitutional democracy is arguably beneficial if it expands the freedom of the previously oppressed as agents to function and do valuable things.

\section{Context}

Development as a concept is itself dicey when examined from the perspective of the liberation paradigm. Some of the doyens of the liberation paradigm have also critiqued the Constitution of South Africa, for example Itumeleng Mosala (2012) and now lately, Mosibudi Magena (2015). The link between development and the Constitution, especially the vision of the national democratic revolution with development is an important discussion for our time, especially when there is a voice that questions the Constitution itself as beneficial to the beneficiaries of our past in South Africa. It is important due to a number of reasons for the failure of sustainable development in Africa, and by this very fact, the failure of development in South Africa. Moeletsi Mbeki's argument that the South African elite are the architects of poverty begs the question of the success of development and constitutionalism after colonialism. He says 'what has gone wrong has been the massive mismanagement by Africa's ruling political elites, with the help of Western powers, of the economic surplus generated in Africa in the past 40 years' (2009:8-9). This Mbeki says in the context of the developmental challenges Africa faces today. As a 'developmental state', South Africa is challenged even more because 'the world is hurled into the whirlwind of economic chaos, political ineptitude, and impending ecological disaster' (Dussel 2008:12 of 13) with a clear growing anti-hegemonic critique on the other hand in which the valorisation of the victims of

Note: This article forms part of the special collection on 'Engaging development: Contributions to a critical theological and religious debate' in HTS Teologiese Studies/Theological Studies Volume 72, Issue 4, 2016. 
injustices suggests "serving the community with obediential exercise of power" for an enhanced participation of the excluded (Dussel 2008: 4 of 13). This means development and its relationship with representation as a model of democracy is even more challenged by participatory notions. 'What then can development as a concept contribute to the struggles of life in South Africa post 1994?

Following these questions, this article examines the relationship between the Latin American dependency theory and the liberation paradigm. In doing so, the attempt is to point to some of the deficiencies of the dependency theory, especially through the insights that informed the liberation paradigm in Latin America, leading the latter to jettison the idea of development in favour of liberation.

Closer home, our question is what role the coloniality of power, or better, the 'colonial wound' (Fanon in Sanjinés 2013) predisposes to the concept of development, especially from the perspective of the Black theology of liberation (BTL). By presenting Sen's capabilities theory therefore, this article demonstrates that there could be a bridge between development and liberation, but still argues that development is an addendum of liberation, given the early critique of the notion even before the appearance of Sen's Theory. In a nutshell, this article does not accept the notion of development, but seeks to engage it so as to establish what the concept itself could present in convergence with the liberation paradigm. A brief allusion to the fundamentals of the national democratic revolution is made to argue for the departure from a developmental state that does development for people rather than with people. Participatory development should thus entail the removal of un-freedoms as the primary task of our government and Constitution rather than the preservation of privilege and rampant political patronage we have hitherto witnessed in South Africa post 1994.

\section{Dependency Theory and the liberation paradigm}

In our conversation with Amartya Sen we should remember that '[i]n the context of liberation theology, feminist theology and later postcolonial theology the very use of the term "development" was challenged, given that it was regarded as compromised upon the assumption of sustained economic growth and Western prescriptions for "economic development" in the so-called Third World' (Klaasen 2013:183). The relationship between Latin American liberation theology and the Dependency Theory is a widely researched area. Most, if not all, Latin American Liberation theologians engaged the Dependency Theory (Penny 1993). According to Teixeira and De Souza (2016), Latin American Liberation Theology interpreted the Dependency Theory, and many of its pioneers provided a theological interpretation of the Dependency Theory.

Teixeira and De Souza say Liberation Theology in its reading of the Dependency Theory interpreted social sciences, 'thus transferring its own reading of the Latin American empiricism to a supposed delimitation of the theological reflection in the realm of faith' (2016:187). Simply put, by engaging the Dependency Theory, Latin American Liberation Theology problematised the dependency of the so-called underdeveloped countries; Latin America in this case, by developing a theology of which the vision is a critique of Christian thought throughout modernity and a socio-political liberation from the dependency of the so-called developed nations. About the theory of development Teixeira and De Souza say:

[It] points to the simple transplant of industrial civilization, this is conceived as a material lifestyle originated outside the historical context of the country concerned. The ideal conditions for this transplant can be confused with social immobility: population is seen by the agents of the industrialization process as a mass of productive resources framed in the laws of markets. An important extension of this ideology is the authoritarianism doctrine as a political system more suitable for late industrializing societies. Only the authoritarian framework could create the ideal conditions for a rapid transplant of industrial techniques and simultaneously intensify accumulation. Political activity is now seen as an oriented effort to reduce the resistance of social structures to the penetration of techniques peculiar to the industrial civilization. Authoritarianism, instrument for achieving higher stages of accumulation, tends to lose its rationale at a later stage of development. In this case as well the evolution of productive forces is presented as a catapult to achieve social forms considered superior [...]. (Teixeiria \& De Souza 2016:190)

The transplantation of civilisation, the civilising mission as it were, framed within the quandaries of the laws of the market with a political system aimed at creating an ideal situation for this transplantation became the pre-occupation of the Dependency Theory and thus its engagement by liberation pioneers. Sabelo Ndlovu-Gatsheni helpfully explains from the perspective of Africa that 'development meant opening up the African continent for economic exploitation and the permanent settlement of the white settlers' (2012:6). He further argues that the defeat of Africa was intrinsically related to development because '[p]olitically, colonial governance assumed the character of a hybrid military/civilian model where violence was a norm of governance.'

'Para-military authoritarianism was a core component of colonial governance, with disciplining of the "natives" being the order of the day' (2012:7). A civilising mission, authoritarianism, economic exploitation and superiority are among the features that are associated with development. Duchrow and Hinkelammert (2004) explain the Dependency Theory in the following manner:

Dependency theory arose in the 1950s and 1960s, accompanying the politics of development as applied there from the Second World War until the 1970s. It was based on a centre-periphery model, according to which the countries of the centre (Europe, and later the USA and Japan as well) built their development for centuries on the underdevelopment of the countries of the periphery-although centres and peripheries may of course be found throughout the world. (p. 142) 
The contradictions related to the concept of development, the development of some through the underdevelopment of others, together with a dominating civilising mission thus let others to speak of liberation. Liberation, according to Teixeira and De Souza, citing Leonardo Boff, 'implied a global rejection of the developmental system and a denunciation of its subduing structure' (2016:192). Liberation thus became a vision for urgency 'to break the system of dependencies' (Teixeiria \& De Souza 2016:192). Mendieta rightfully argues that the Liberation Theology has a pre-history and a number of factors that could explain its emergence. He enumerates about eight of these factors such as the Cuban Revolution (1959), the well-known Medellin (Columbia) Conference (1968), the manifesto of the Liberation Theology (1968) and others including the emergence of the Dependency Theory - Desarrollismo. The Cuban Revolution was regarded as an example of the 'possibility for an alternative path of development "outside the world capitalist system"' (Grosfoguel 2008:316) and in Latin America it led to the emergence of the Dependency School. Later on the Liberation School found the Dependency Theory School inadequate as an alternative path of development. Our point thus far is that the break with the Dependency Theory, which constituted the pre-history of the liberation paradigm, led to the emergence of liberation as a paradigm that constituted a break from the system of dependencies.

The centre-periphery model of development which led to the underdevelopment of other countries - rendering the socalled underdeveloped countries as stepping stones for the so-called developed others, is in fact the epitome of the ethical question the liberation school has grappled with and thus the hermeneutics of suspicion to which the concept of development has been subjected and should continue to be subjected. It is the views expressed by Ramon Grosfoguel that we find helpful in deepening the thrust of our conversation in this regard, especially the critique of the Dependency Theory.

Grosfoguel posits development as part of the ideology of modernity. He presents an elaborate exposition to illustrate that developmentalist debates existed for centuries in Latin America and that despite some of their seemingly radical positions, these development debates of 1945-1990 in Latin America should be viewed as part of the long history of the geo-culture of modernity. 'Developmentalism' according to Grosfoguel, '[is] linked to liberal ideology and to the idea of progress' (2000:348). This view by Grosfoguel is not dissimilar from Enrique Dussel's hypothesis of the 'World System' (2002:222-224) deployed by those who critique the concept of development from the underside of modernity. This hypothesis responds 'to the first Eurocentrism, which thought that Europe, since its supposed Greek and Medieval Latin origins, produced "from within" the values and the instrumental systems (as argued by Hegel, Marx, Weber, and Sombart) that were universalised in the last five centuries that is, in the time of modernity'(2002:222).
This view - the view that Europe produced values and systems from within itself - led to Eurocentric exponents such as Hegel imagining Europe as the end and centre of world history' (2002:222). Following this, development as a concept and its links with the liberal ideology and the idea of progress - with Eurocentrism - inevitably meant that by the very beginnings of modernity, the periphery was 'infant' and thus underdeveloped. According to Dussel, the Latin American Dependency Theory is better understood when subsumed under perspective of the 'World System' and Eurocentrism.

As the end of the 19th century debates were Comptian and thus fraught with positivistic science, development could not escape the same spirit of Eurocentrism which created a dualistic tension between society as a new construct and community as a distinct one, urban and rural, religious and secular and so forth - a bifurcated space a la Mamdani. Indeed, many South Africans will know the dichotomies between amaqaba and amaqgoboka, bifurcated concepts (Vellem 2015) in relation to the socio-historical order of the global South at the encounter with modernity and the civilising mission of the West. Sabelo Gatsheni-Ndlovu (2013) renders this similar sentiment in this manner:

Because of the coloniality of power, Africa found itself at the interface between different value systems, different forms of logic: Western and African; urban and rural; patriarchal and matriarchal; religious and secular; nationalist and tribal/ethnic; modern and traditional; progressive and conservative; cultural and technical: the list is long. (pp. $42-43$ of 57)

In a nutshell, in the light of Eurocentric dualistic views and positivistic science, the concept of development is deeply understood when put under the spotlight of the coloniality of power, meaning the presence of colonial matrices of power long after the independence of an African state. For example, national development and the inevitable progress of the nation-state through the rational organisation of society as the dominant feature of modern society is translated into an independent African state as a panacea of development. Eduardo Mendieta says:

In a theology of liberation, Gutierrez began the paradigm shift that would take Latin American theology away from abstract philosophy to the social sciences, away from the fallacy of desarrollismo to a historical theology of 'liberation', away from the conceptual naiveté and self-deceiving autonomy of European theological discourse to self-conscious, self-critical, engaged theological reflection. It is not without justification that Liberation Theology has been called a second Reformation. (Introduction 1996:xx)

Liberation Theology, from a World Systems perspective, thus posits a particular relationship with the concept of development. In the light of the liberation paradigm development as a concept has to be denuded of its links with liberalism, abstract philosophy and a self-deceiving autonomy. Desarrolismo is thus a fallacy! To have a fuller grasp of the fallacious logic of the concept of development, the deployment of the hypothesis of the 'World System' as 
a response to Eurocentrism and the dualistic concepts that even find expression in the lives of the victims for colonial purposes remains indispensable. But how is the Dependency Theory fallacious in itself if it constituted the pre-history of liberation? This we respond to by looking at development from the perspective of those who occupy the peripheries as distinct from the occupants of the centre within the World System approach.

\section{Development from the underside of modernity}

Ramon Grosfoguel offers an elaborate exposition of contradistinctions related to developmentalism within modernity which include inter alia, stageism, abstract dichotomies that conceal domination and exploitation, the penetration of the civilising ideals of the centre in the periphery, temporal and spatial deficiencies accompanied by the capitalist system, all rightly exposed by the Dependency Theory (Grosfoguel 2008:319-320). His argument nonetheless, is that the school itself had three basic limitations: the trap of the school in developmentalism, the denial of coevalness and the concealment of coloniality of power in Latin America. In other words, the Dependency Theory, as 'part of a longue duree of the ideology of modernity' implied that the school was 'caught up in developmentalist assumptions similar to the intellectual currents they attempted to criticize' (2008:330). Dependency Theory underestimated the coloniality of power in a nutshell.

Ndlovu-Gatsheni, discussing the concept of development in relation to Africa, explains the coloniality of power as 'a major component of the world-systems approach and critical concept underpinning decolonial epistemic perspectives' (2012) which cannot be overlooked when the discourse of development is engaged. He says:

Coloniality is an invisible power structure that sustains colonial relations of exploitation and domination long after the end of direct colonialism. Coloniality of power works as a crucial structuring process within global imperial designs, sustaining the superiority of the Global North and ensuring the perpetual subalternity of the Global South using colonial matrices of power. (p. 3)

In this regard, namely the invisibility of the power structures of colonialism after its 'end', the perpetuation of its structures and the subalternity of the periphery, NdlovuGatsheni (2012) identifies four types of the colonial matrices of power:

The first is control of economy which manifests itself through dispossessions, land appropriations, the exploitation of labour, and control of African natural resources. The second is control of authority which includes the maintenance of military superiority and monopolization of the means of violence. The third is control of gender and sexuality which involves the re-imagination of 'family' in Western bourgeois terms and the introduction of Western-centric education which displaces indigenous knowledge. The last is control of subjectivity and knowledge which includes epistemological colonisation and the re-articulation of African subjectivity as inferior and constituted by a series of 'deficits' and a catalogue of 'lacks' (Grosfoguel 2007:214; Quijano 2007:168-187). (pp. 1-2).

Without belabouring these sentiments, it is undeniable that they precisely express the experience of those who live on the underside of modernity. Development from the underside of modernity is thus not an obnoxious concept, as it entails the history of dispossession, cheap labour, control of Africa's natural resources, military violence, sexuality and epistemicide. Rightly so, according to Frantz Hinkelammert and Ulrich Duchrow, one of the challenges we need to contend with in the current globalising world is 'the handing over of the planning functions of the economy to the multinational companies, and the surrender of the workforce and nature to the market' (2004:142).

Moeletsi Mbeki is among those who have argued that our South African economy since the demise of apartheid has not been touched, leaving the African National Congress-led government only with political power and thus political patronage. In the context of neoliberal economics, which is the case in South Africa today, the handing over of the economy to other platforms is plausible when one remembers how South Africa chose to adopt the most conservative macro-economic policies upon departing from the Reconstruction and Development Programme (RDP) early after assuming power in the 1990s. In a nutshell, development creates temporal deficiency by concealing the responsibility of the North in the exploitation of the South to present the history of the world as constituted by different times as a result of different geographical spaces and thus to present them as unrelated. Different temporalities in which Europe is seen as a model more advanced than others having to catch up, creates the problems of dichotomies, foreignness and the displacement of indigenous knowledge and the articulation of African subjectivity as inferior. The concept of the 'coloniality of power' by Quinjano clarifies the contradictions of developmentalism by revealing the imbrications of development within categories of modernity constructed along dualities; bifurcation, white control of the economic, cultural and political structures (Grosfoguel 2008:327). Coloniality is a socio-cultural relationship between Europeans and non-Europeans that is constantly reproduced as long as the power structures are dominated by the white elites and the cultural construction of non-European people as 'inferior others' continues (Grosfoguel 2008:327).

The liberation paradigm in its social analysis, by beginning from the World System in its quest for social transformation critiques the Dependency Theory as essentially a school located in the geo-culture of the North and much more focused on academic transformation (Mignolo 2008:231). Liberation thus seeks to break from the trappings of developmentalism, the deficient temporalities and spatiality of the centre and the hiddenness of the colonial matrices of power. 
Let us now proceed to reflect on Sen's Theory of capabilities, to further assess the relationship between 'development' as a concept with the liberation paradigm.

\section{Amartya Sen's capabilties theory}

The conversation about Sen's Theory on capabilities started a few years ago and much of what is said here is influenced by the insights and debates on the concept of development in its relationship with the construction of a new order in post1994 South Africa (Vellem 2007). We shall not therefore present an elaborate exposition of Sen's work, but the central tenets that emanate from his theory for the conversation that primarily seeks to demonstrate the tension that exists between the concepts of development and liberation. Our own view of the theory is that at its core Sen's Theory of capabilities entails the removal of 'un-freedoms'. In our application of this theory, our argument is that Sen's Theory is helpful in pointing us to the eradication of the obstacles that hinder the comprehensive liberation of the marginalised. Sen argues that development is freedom, and his thesis provides a link in the tension and debates that have been propounded between development and liberation. The removal of un-freedoms resonates with the break with the systems of dependencies as suggested by the liberation paradigm we have already identified above.

According to Vat Til, Nobel laureate Amartya Sen thoroughly critiques mainstream economics (2008:85-88). Sen proposes a different standard for measuring economic success than that of mainstream economics, namely 'basic capabilities':

By basic capabilities Sen means 'the ability to do valuable acts or reach valuable states of being'. Sen's focus is the capability of humans to function freely. A person is an agent, and the agent must be able to act. Sen puts it his way: "This "agency aspect" takes a wider view of the person [than merely "well-being"], including valuing the various things he or she would want to see happen, and the ability to form such objectives and have them realized'. (Vat Til 2008:85)

Flowing from above, development as a concept should be evaluated by how it provides human beings with the capability to achieve 'crucial functionings' (Vat Til 2008:85). The capability of a human being to function because a human being has shelter, breathes clean air, can participate in the political community and that a human being has his/her dignity affirmed is the hallmark of the capabilities theory. Amartia Sen argues that, while we live in a world of unprecedented opulence, the paradox is that we also live in a world with remarkable deprivation, destitution and oppression. The persistence of poverty coupled with unfulfilled elementary needs is appalling according to him. For him 'the question of whether a person has the ability to function as a human being is both a moral and an economic one' (Vat Til 2008:87).

Sen sees the role of freedoms of different kinds to be central in countering the afflictions of poverty and unfulfilled needs of the human beings. Accordingly, individual agency becomes central in addressing the deprivations mentioned above. What needs to be recognized is that the freedom of agency is inevitably constrained and qualified by the social, political and economic opportunities that are available in a given situation. Individual freedom, Sen proposes, must be seen as a social commitment. (Vellem 2007:228)

In his argument for development as freedom, Sen argues that there are five types of freedoms: political, economic, social, transparency guarantees and protective security. All these freedoms help enhance the general capability of an individual and the enhancement of agency.

The gap between an exclusive concentration on economic wealth and a broader focus on the lives we lead is central for the conceptualisation of development in Sen (1999:14). The value of wealth lies in the things that it allows us to do. According to Aristotle, 'wealth is merely useful and for the sake of something else', Sen retorts.

Liberation from different kinds of oppression or obstacles that hinder one's comprehensive liberation is important to counter impoverishment. At best, the enhancement of agency is indispensable for the eradication of un-freedoms and thus the deprivations that undermine the dignity of the marginalised. Agency is related to the social, political and economic, Sen rightly argues. Sen thus expands the notion of freedom. In this manner, freedom becomes the telos of development and ipso facto, liberation - comprehensive liberation - becomes the telos of development, we add. To remove substantial 'un-freedoms' constitutes development. 'The linkages between different types of freedoms are empirical and causal, rather than constitutive and compositional' (Sen 1999:xii) he explains. In postulating that development is freedom, Sen defines development as a process of expanding the real freedoms that people should enjoy (1999:3). According to this definition, freedom depends on other determinants such as social and economic arrangements. The removal of un-freedoms such as poverty, tyranny, poor economic opportunities, and systematic social deprivation, is a quid pro quo for development as freedom. Development as freedom and how it related to liberation is the perspective or line of argument we take as the paradigm of liberation is not the same as that of liberalism.

\section{Liberation as development}

We should come closer to our conclusion by briefly appropriating the understanding of development as freedom or capabilities theory within our paradigm of liberation. Leornado Boff (2014) says:

The first concept that needs revision is development. In practice, it is identified with material growth, measured as gross domestic product. Its dynamic consists of growing as large as possible to infinity, which has led to a pitiless exploitation of the natural world and an increase in national and international inequality. We must abandon such a quantitative understanding and adopt instead a qualitative understanding. The latter defines development, as Amartya Sen put it so well, as 'a process of expanding real freedoms', that is to say, an enlargement of opportunities to shape one's own life and to give it a compelling meaning. (pp. 1 of 4 ) 
Indeed, we have already made the point about breaking the systems of dependencies and subjecting the concept of development to critique as part of the geo-culture of modernity with the implication of the myth of Europe as the end. From the underside of modernity, we have seen how the coloniality of power debunks the linearity and temporality of the concept. In line with Sen, it is the qualitative view of development as the process of expanding real freedoms, perhaps, when put the other way around, an expansion of the removal of un-freedoms, the liberation paradigm should follow. Development in this manner is a struggle against unfreedoms. As liberation theology was developing, development schools were also developing together with dependency theories (Duchrow \& Hinkelammert 2004:143145; Gutierrez 1999:22-23).

One further illustration of the appropriation of the capabilities theory is Cyhtnia Holder-Rich's. Holder-Rich engages Amartia Sen's thesis that '[d]evelopment is dreedom' in a Christian dialogue to explore the implications of Sen's ideas for the church and development. She appreciates the proposition of development as freedom and perceives the Christian focus on freedom as an entry point of engaging with Sen's proposition. She dialogues with Sen around three key themes of agency, advocacy and empowerment. According to Holder-Rich, the key question raised by Sen's seminal work is what the role of the church is in the promotion of freedom in society and the church itself. Holder-Rich (2001) says:

Sen starts with 'development'; I turn this question around and start with 'freedom', as freedom is, I believe, the central issue of the Christian faith. Among the many ideas Sen elucidates in his work that have special meaning for Christians, I have chosen three to address here: 1) the church as an agent of freedom;2) the church as an advocate of freedom; and 3) the church as an empowerer (as an agent of empowerment) of all people for freedom, especially those on the margins of society. (p. 92)

The church as an agent of freedom is a powerful ecclesiological symbol presented by Holder-Rich. Chapter five of her doctoral work is entitled: 'Freedom as development Elements of a liberating ecclesiology' (2003:208-273). Taking her cue from Sen, Holder-Rich defines an agent as someone who brings about change. She concludes that 'work that leads toward freedom for people within the church, for families, for communities and for societies - is part of the call of Christians' (2001:93). Sen's articulation of freedom as we have seen expands the notion itself and is comprehensive. For us therefore, the gospel of Jesus as liberation, places comprehensive liberation as development in Sen's sense. Our model is the vision of another kind of development promoted through thinkers like Mahatma Gandhi, Julius Nyerere, Paulo Freire and Steve Biko. This is a process of development in which the marginalised seek to become subjects of their own history rather than objects of someone else's story (De Gruchy 2001:75). Biko's vision undergirds the vision of the lack theology of liberation. Our vision of development as liberation thus perceives the marginalised as subjects of their own history participating in the expansion of freedoms and making a compelling meaning of their lives where their lives do not matter. Arguably, development is an addendum to the project of the Black Theology of liberation if it developed to what Sen has seen it to be. Indeed it must be remembered that while development became current after the independence of many African and Asian states:

From the beginning, however, the Asian-African leaders in the ecumenical movement questioned the development model that did not include a concomitant focus on righting the historic wrong of social injustice and structural violence. They affirmed that the notions of social justice and self-reliance have to radically re-define the meaning of development. (Athyal 2016:13)

These views in the ecumenical movement were already expressed in the late 1960s, which saw nothing but the righting of the historic wrongs of social injustice and structural violence as crucial. One of the Asian doyens of liberation put it in the following manner:

People's struggles against poverty and oppression in India and elsewhere in the Third World require clear models of development which comprehend politics of the struggle and renewal of culture and appropriate technology within them in such a way that they not only liquidate poverty but also build 'a just participatory and sustainable' society in all parts of the earth. (Athyal 2016:13)

Our point here is simple. The critique of development by the liberation paradigm is old and insights against models of development that were devoid of the struggles against poverty and oppression should not be overlooked. For a number of years this has been the reason for the chasm between development and liberation. The proposition by Amartia Sen, his capabilities theory, came around to affirm the long established view of development by the liberation school, namely that development is freedom - a break from systems of dependencies, a break from un-freedoms.

\section{Development and the national democratic revolution in South Africa}

The implications of this discussion for our constitutional democracy are obviously numerous. Flowing from this, one general point should be made given the limitation of our space. Constitutional democracy is liberative if the tyranny of the modern democratic state and its values cannot plunge ordinary people into a state of famine and other forms of un-freedoms. Constitutional democracy in South Africa is liberative when it releases the country from the trappings of developmentalism and the temporalities and spatialities created by the Euro-American myth as the centre of the world. At a metaphysical level, the capabilities theory provides the South African developmentalist state with important lessons in its understanding of development. Development as seen through Sen's lenses and the liberation paradigm is better when viewed qualitatively and cautions the link between a developmentalist state with 'growth and development' - the macro-economic policy trajectory in South Africa that has continued to fail the poor. Service delivery protest should ostensibly be 
viewed as an indication of a state doing development for people and not with people. Any approach that throttles the agency of the poor in development is surely bound to fail. The emergence of the Fallist or the Decolonising Movement in South Africa twenty two years after democracy makes the question about the foundations of the developmentalist state even more urgent. The tyranny of a neoliberal democratic state has been well expressed in the tragic Marikana Massacre.

\section{Conclusion}

This article examined the relationship between the Dependency Theory and the liberation paradigm. Liberation while engaging the Dependency Theory, moved away from it in the quest for breaking with the systems of dependencies. From the underside of modernity, development has to deal with the coloniality of power, the matrices of the colonial power that trap the South in the temporalities and spatial designs of the North. Sen's Theory of capabilities essentially expands the notion of freedoms and as a liberative concept calls upon the exponents of liberation to struggle against un-freedoms that dent the agency of the black to function and do valuable acts in the country of their birth.

\section{Acknowledgements Competing interests}

The author declares that he has no financial or personal relationships which may have inappropriately influenced him in writing this article.

\section{References}

Athyal, J., 2016, 'M.M Thomas's Theology of society: An overview', in J. Athyal, G. Zachariach \& M. Melachthon (eds.), The life, legacy and theology of M.M. Thomas, pp. 9-29, Routledge, London.
De Gruchy, S., 2001, 'Introducing the United Nations Millennium Declaration', Journal of Theology for Southern Africa 110, 57-76.

Duchrow, U. \& Hinkelammert, F.J., 2004, Property for people, not for profit: Alternatives to the global tyranny of capital, Zed Books, London.

Dussel, E., 1996, The underside of modernity: Apel, Ricoeur, Rorty, Taylor, and the Philosophy of Liberation, Humanity Books, New York.

Dussel, E., 2008, Twenty Thesis on Politics, Duke University Press, London.

Grosfoguel, R., 2000, 'Developmentalism, modernity, and dependency theory in Latin America', Neptlanta: Views from the South 1(2), 347-374.

Grosfoguel, R., 2008, 'Developmentalism, modernity, and dependency theory in Latin America', Moraña, M., Dussel, E. \& Jauregui, C.A. (eds.), 2008, Colonialiaty at large, pp. 307-347, Duke University Press, Durham.

Gutierrez, G., 1999, 'The task and content of liberation theology', Transl. Judith Condor, in C. Rowland (ed.), The Cambridge companion to liberation theology, pp. 19-38, Cambridge University Press, Cambridge.

Klaasen, J., 2013, 'The interplay between theology and development: How theology can be related to development in postmodern society', Missionalia 41(2), 182-194.

Magena, M., 2015, Triumphs and Heartaches. A courageous journey by South African Patriots, Picador, Johannesburg.

Mendieta, E., 1996, (Introduction: XX) in Dussel E, The underside of modernity : Apel, Ricoeur, Rorty, Taylor, and the Philosophy of Liberation, Humanity Books, New York.

Mosala, I., 2012. "The State of Grass Roots Struggles and Organizations: Lessons from Dr Beyers Naude," Public Lecture on the 17th October 2012, at Midrand, organised by Esset.

Ndlovu-Gatsheni, S., 2012, 'Coloniality of Power in Development Studies and the Impact of Global Imperial Designs on Africa', Inaugural Lecture Delivered at the University of South Africa, Senate Hall, 16 October.

Ndlovu-Gathseni, S., 2013, Empire, global coloniality and African subjectivity, Berhahnm, New York.

Mignolo, W. D. 2008. "The Geo-politics of Knowledge and the Colonial Difference," in Moraña, M., Dussel, E. \& Jauregui, C.A. (eds.), 2008, Colonialiaty at large, Duke University Press, Durham 225-258.

Penny, J., 1993, 'Hunger for bread, Hunger for God: Latin American perspective', Religion, State and Society 21(1), 9-20.

Sanjines, J. 2013, Embers of the Past: Essays in Times of Decolonization, Duke University Press, London.

Sen, A. 1999. Development as Freedom. Oxford: Oxford.

Teixeiria, H.A.C. \& De Suoza, E., 2016. 'Liberation and dependency: A theological reading of social sciences in Latin America', Missionalia 43(2), 186-194.

Vat Til, K., 2008. 'Human nature and human needs in recent Economic Theory', in D.A. Hicks \& M. Valeri (eds.), Global neighbors: Christian Faith and mora obligation in today's economy, pp. 65-88, Wm.B. Eerdmans, Grand Rapids, MI.

Vellem, V., 2007, 'The symbol of liberation in South African Public life: A black theological perspective', Ph.D. Thesis, Dept of Systematic Theology and Ethics, University of Pretoria, Pretoria.

Vellem, V.S., 2015, 'Black ecclesiology: Uprising faith praxis for the blackness of humanity', Ecumenical Review 67(4), 656. 